\title{
PREFACE
}

Volumes XXXVI and XXXVII of Orient (Reports of the Society for Near Eastern Studies in Japan) were conceived by the editorial board in 1999. At the turn of the century, we felt the need to look back on how Near Eastern studies emerged in our country and developed throughout the 20th century, and to record it in English so that we could share the history of Japanese scholarship in this field with the rest of the world. The idea was immediately approved by the directors of the society, and we set out to compile two special volumes: Volume XXXVI covering the pre-Islamic period, and Volume XXXVII covering the period thereafter. The task has not been an easy one, but thanks to the collaboration of current and former members of the editorial board, Volume $\mathrm{XXXVI}$ is now ready for print, though belatedly.

In this volume are presented eight articles roughly covering the field of Ancient Near Eastern (ANE) studies in its widest sense: archaeology, Assyriology, Egyptology, Middle Iranian studies, Biblical studies, Hellenistic studies, Byzantine studies, and linguistic studies of ANE languages. A few remarks are due. First, there is no article on Ancient Iranian studies. An article on this subject is under preparation by Toyoko Kawase, and will be published in Vol. XXXVII. One might also expect an independent article about ANE art, but it has been incorporated into the relevant articles below. The article on Biblical studies also needs further comment. Since it is a vast field with an enormous number of publications, it is impossible to mention all the relevant academic works. So the author intentionally focused on the non-theological study of the Old Testament, which is the branch among the extensive branches of Biblical studies in which the members of the Society for Near Eastern Studies in Japan (SNESJ) are most interested.

Many of the books and articles listed in the bibliographies in this volume are written in Japanese. Those items have been cited in the following manner. First, the name of the author(s) in Roman script and the publication year are given. Next, the name of the author(s), the title of the book or the article and other relevant bibliographical information are cited in Japanese. Finally, their translation into a European language is appended. If no authoritative translation was available, the editor(s) provided one (in square brackets). Japanese journals are normally cited according to their romanized titles (e.g. Shigaku Zasshi)

Vol. XXXVI 2001 
rather than their translation into a European language (e.g. The Journal of History) except for those containing foreign proper nouns (e.g. The Journal of Egyptian Studies). The name of the institution or organization which issues the journal in question is also indicated each time except for the common ones (see abbreviations in pp. 5-6 below).

On behalf of the editors of the present volume, I would like to thank Mrs. Susan Tsumura for her effort in checking and correcting the English of all the articles in this volume and for giving many valuable suggestions.

As an introduction to the eight articles, let me describe here in brief the history of ANE studies in Japan, based partly on Prince Takahito Mikasa's article, "In Retrospect: Ancient Near Eastern Studies in Japan" (Bulletin of the Society for Near Eastern Studies in Japan 43/2, 1-14, in Japanese).

When Europeans rediscovered the Ancient Near Eastern civilizations and deciphered hieroglyph and cuneiform scripts, Japan was secluded from the rest of the world under the reign of the Tokugawa Shogunate, which banned almost all contact with foreign countries. In 1867, the samurai government came to an end, and a new era called Meiji (1868-1912) started.

Meiji was the period in which Japan encountered the western civilization and vigorously absorbed its culture and science. Imperial universities were founded in nine major cities across the country such as Tokyo, Kyoto, and Osaka, and chairs for various fields of studies were created. Japanese were eager to study about the western culture including Greek and Latin classics, besides traditional studies. This attitude led to a unique tripartite division of historical studies in Japan into Japanese, Eastern (virtually "Chinese"), and Western history. The Near East fell into a gap among the three and somehow fell out of the academic disciplines in Japanese universities.

The next era Taisho (1912-1926) was a transitional period. In 1922, a chair for the academic study of Christianity was created in Kyoto University, and four Christian universities-Doshisha University, Kyoto, Rikkyo University, Tokyo, Sophia University, Tokyo, and Kwansei Gakuin University, Hyogo-were founded in the 1920's and 30's. In 1934, the Society for Old Testament Studies in Japan was inaugurated. With these events, Biblical scholarship in Japan had begun.

On the other hand, ANE studies were carried out extracollegiately. Not even a single chair of Assyriology or Egyptology was created, but 29 laymen who had keen interest in the ANE civilizations got together in 1917 in Tokyo, 
and founded the Babylon Society. The society was run by generous donations from business circles, which covered book and other allowances of the researchers as well as publication of the society's periodical Babylon. In 1923, however, the Great Kanto Earthquake struck Tokyo, and the society's building and books were destroyed by fire, and it could not continue its activities.

After the World War II, serious professional ANE studies finally began. They involved education, societies, excavations, and exhibitions.

First, after the World War II, several scholars earnestly taught ANE history and languages at Japanese universities. Among them were Namio Egami (archaeology) and Kiyoshi Ohata (Judaism) of the University of Tokyo, Atsuuji Ashikaga (Ancient Iranian studies) and Yomokuro Nakahara (Sumerology) of Kyoto University, Masao Sekine (Biblical studies and ANE languages) and Isamu Sugi (ANE history) of the Tokyo University of Education, Kiichi Kawamura (Egyptology) of Waseda University, and Rainosuke Awano (Hellenistic studies) of Kwansei Gakuin University. They trained directly and indirectly many able students. These second-and-beyond generation scholars have become leading scholars of ANE studies in Japan today, some of whom went to Europe, the U.S. or Israel to study toward Ph.D. in various fields of ANE studies.

Second, several new societies related to ANE studies were founded from the 1950's on. The most important one was the Society for Near Eastern Studies in Japan, founded in 1954. It was initiated by Prince Takahito Mikasa, who became the first president of the society. The society started with 64 members, and today its members number more than 700 . Other associations related to ANE studies include the Japanese Biblical Institute founded in 1950, the Paleological Association of Japan founded in 1951 by Bun'ei Tsunoda, the Association for Egyptian Studies (the forerunner of Institute of Egyptology) of Waseda University founded in 1965 by K. Kawamura, the Association for Sumerian Studies founded in 1973 by Y. Nakahara, which issued the first volume of Acta Sumerologica in 1979, and the Japanese Society for Western Asian Archaeology founded in 1997. Besides, three museums devoted to the ANE art and antiquities opened in the 1970's: the Ancient Orient Museum founded in 1978 in Toshima-ku, Tokyo, the Middle Eastern Culture Center in Japan founded in 1979 in Mitaka-shi, Tokyo, and the Okayama Orient Museum founded in 1979 by the city of Okayama. These associations and museums have developed a critical mass of scholars and students for generating quantitative and qualitative progress in ANE studies in Japan. 
The third element in post-war developments in ANE studies in Japan is the increasing number of excavations in the Middle East which have been carried out by Japanese missions (see the article of K. Matsumoto and K. Oguchi for details). Moreover, thanks to a strong yen, it has become affordable for Japanese institutions to send archaeological expeditions abroad and for Japanese students to participate in digging at Middle Eastern cites. ANE artifacts and inscriptions are no longer something one can view only in a book or through a showcase window. Exposure to primary sources has had an immeasurable impact on ANE studies in Japan.

The final element concerns exhibitions of ANE material. From the 1950's on, there have been many exhibitions of Mesopotamian, Egyptian, Persian, Turkish art and antiquities. In 2000, for example, there were two very successful ones, the World's Four Great Civilizations Exhibitions and the Tokyo Great Bible Exposition. The former consisted of four simultaneous exhibitions from Egypt, Mesopotamia, Indus and China at separate museums, and a total of over 1.8 million people came to see the four exhibitions. The latter featured a piece of a Dead Sea scroll and attracted 52,000 attendants. This shows that not only scholars and students but also wide range of the general public are increasingly interested in the ANE.

Though ANE studies in Japan thus advanced steadily after the World War II, and the attention of the general public to this field has increased rapidly, there is still not even one single chair of ANE studies in Japanese universities. This means that all the professors mentioned in the following articles belong to departments which are only partially related to ANE studies, e.g. that of archaeology, Western history, religious studies, linguistics, etc. They happen to be in their position, and there is no guarantee that their successor will be an ANE specialist. For this reason, traditions of ANE studies in Japan are mostly transmitted through intercollegiate associations and study groups. This has some positive aspects indeed, yet we definitely do need a chair or two of ANE studies in Japan as centers where the academic tradition can be transmitted continually and books and journals can be accumulated without a break.

With this modest hope in mind, we need to work harder than ever to produce quality academic works in the international arena as well as to demonstrate here in Japan the importance of dialogue between the modern and the ancient in general and between Japan in the 21 st century and the ANE in particular.

Jun Ikeda 


\section{Abbreviations of Journals}

AJBI: Annual of the Japanese Biblical Institute, Institute of Biblical Studies in Japan (日本聖書 学研究所).

al-Räfidān, Journal of Western Asiatic Studies, The Institute for Cultural Studies of Ancient Iraq, Kokushikan University.『ラーフィダーン』国士舘大学イラク古代文化研究所.

ASJ: Acta Sumerologica, Middle Eastern Culture Center in Japan (中近東文化センター).

Balkan and Asia Minor Studies, Research Institute of Civilization, Tokai University. 『バルカン. 小アジア研究』東海大学文明研究所.

BAOM: Bulletin of the Ancient Orient Museum, The Ancient Orient Museum (古代オリエント博 物館), Tokyo.

BMECCJ: Bulletin of the Middle Eastern Culture Center in Japan, Middle Eastern Culture Center in Japan (中近東文化センター).

BSNESJ: Bulletin of the Society for Near Eastern Studies in Japan.『オリエント』日本オリエン 卜学会.

BSWSAS: Bulletin of the Society for Western and Southern Asiatic Studies, Kyoto University. 『西 南アジア研究』京都大学.

Chichukaigaku Kenkyu (Mediterraneus), The Collegium Mediterranistarum, Japan. 『地中海学研 究』地中海学会.

Exegetica, Association for Old Testament Exegesis.『Exegetica』旧約釈義研究会.

Jimbun Ronkyu (Humanities Review), Kwansei Gakuin University. 『人文論究』関西学院大学.

Jinbun Kenkyu (Studies in the Humanities), Faculty of Literature, Osaka City University. 『人文 研究』大阪市立大学文学部.

Kirisutokyo Ronshu (Journal of Christian Studies), Aoyama Gakuin University. 『基督教論集』青 山学院大学基督教学会.

Kodai Bunka (Cultura Antiqua), Paleological Association of Japan, Kyoto.『古代文化』古代文化 協会.

Kokogaku Zasshi (Journal of the Archaeological Society of Nippon).『考古学雑誌』日本考古学 会.

Kwangaku Seiyoshi Ronshu [Studies in Western Hsitory], Kwansei Gakuin University. 『関学西 洋史論集』関西学院大学.

Kwansei Gakuin Shigaku (The Historical Studies of the Kwansei Gakuin University). 『関西学院 史学』関西学院大学.

Nidaba, Liguistic Society of Western Japan, Hiroshima.『ニ゙バ』西日本言語学会, 広島.

Orient (Reports of the Society for Near Eastern Studies in Japan). 日本オリエント学会欧文紀要.

Rekishi Hyoron, Japan Association of Democratic Scientists. 『歴史評論』民主主義科学者協会.

Rekishigaku Kenkyu (The Journal of Historical Studies), The Historical Science Society of Japan. 『歴史学研究』歴史学研究会.

Seishogaku Ronshu (Biblical Studies), Institute of Biblical Studies in Japan. 『聖書学論集』日本 聖書学研究所.

Seiyo Kotengaku Kenkyu (Journal of Classical Studies), The Classical Society of Japan. 『西洋古 典学研究」西洋古典学会. 
Seiyoshi Kenkyu (The Study of European and American History), University of Tohoku. 『西洋史 研究』東北大学文学部西洋史研究会.

Seiyoshi Ronso (Studies in Western History), Historical Society of Waseda University, Western History. 『西洋史論叢』早稲田大学西洋史研究会.

Seiyoshigaku (The Studies in Western History), The Japanese Society of Western History.『西洋史 学』日本西洋史学会.

Shigaku Kenkyu (The Bulletin of the Tokyo Kyoiku University Literature Department), Tokyo University of Education. 「史学研究』東京教育大学.

Shigaku Zasshi (The Journal of History), The Historical Society, Japan.『史学雑誌』史学会.

Shikan (The Historical Review), Waseda University. 『史観』早稲田大学史学会.

Shikyo (En Marge de l'Histoire), University of Tsukuba. 『史境』歴史人類学会, 筑波大学.

Shingaku Kenkyu [Theological Studies], Kwansai Gakuin University. 『神学研究』関西学院大 学.

Shirin (The Journal of History), Kyoto University. 『史林』京都大学史学研究会.

Shisen, Society for Historical and Geographical Studies in Kansai University.『史泉』関西大学史 学会.

The Journal of Egyptian Studies, Waseda University.『エジプト学研究』早稲田大学エジプト 学会.

Toho Gakuho (Journal of Oriental Studies), Institute for Research in Humanities, Kyoto University. 『東方学報』京都大学人文科学研究所.

Zinbun, Annals of the Institute for Research in Humanities, Kyoto University. 